Jpn. J. Oral Biol., $40: 36-41,1998$.

\title{
ORIGINAL
}

\section{Nerve distribution on the capillary network of molar gingiva in golden hamster by the silver impregnation method}

\author{
Jung-Kwang Chen, Jung-Chou Liang, Min-Ying Liao and Yohichiro Nozaka \\ First Department of Oral Anatomy, School of Dentistry, Iwate Medical University \\ (Chief : Pro. Yohichiro Nozaka) \\ 1-3-27, Chuo-dori, Morioka 020-0021, Japan
}

〔Received on September 22, 1997 ; Accepted on November 6, 1997〕

Key words : whole mount gingival specimen/India ink injection/silver impregnation

\begin{abstract}
The nerve distribution on the capillary network of mandibular buccal molar gingiva in golden hamsters was studied by the silver impregnation method. By employing silver impregnation on India ink injected whole mount gingival specimens directly, we could observe the distribution of nerve fibres on the capillary network three-dimensionally. In addition, by this method, troublesome graphic reconstruction sections could also be prevented. Silver impregnated nerve fibres appeared at the periosteum of the alveolar bone and formed bundles. The full running course of the bundles of nerve fibres accompanied by blood vessels, ran longitudinally along the outer surface of the alveolar bone. When entering free gingiva, the course of the nerve fibres was random. Nerve fibres branched into many smaller branches, ran in the direction of the connective tissue papillae and formed mesh-like nerve plexuses underlying the mucosa epithelium of the gingiva. Single nerve fibres emanating from these plexuses, ran toward capillary loops and were distributed not only at the base portion of the arterial limb and the venous limb but also extended to the middle portion of the former and the latter. Single nerve fibres extended to the tip of the capillary loops, however, the so-called true capillaries, were not found.

In conclusion, it is suggested that these nerve fibres may be involved in the endothelial cells of capillaries. Through transmission of efferent signals, nerve fibres perhaps play an important role in regulating the blood flow of the capillary network in the mandibular buccal gingiva.
\end{abstract}

抄録：鍍銀法を用いてゴールデンハムスター曰歯部歯肉の毛細血管の神経分布を調べた。墨汁を注入した歯肉 の全載標本に直接鍍銀法を施すことにより，毛細血管に分布する神経線維を立体的に観察することができた。こ の方法により，煩雑な立体再構築標本の作製を避けることができた。歯槽骨骨膜に鍍銀神経線維が束を成して認 められた。これらの神経線維の経路は, 歯槽骨に沿って上行する神経線維束が歯槽骨外側面に沿って上行する血 管と伴行し, 遊離歯肉に入ると枝分かれをしながら歯肉粘膜上皮下の結合組織乳頭へと向かって走行した。粘膜 上皮直下には神経線維は神経叢を形成していることが観察された。神経叢からの枝は毛細血管グループ動・静脈 脚の基底部に到達し，さらに動・静脈脚の中間部までに叢状に分布していた。しかし，毛細血管ループの尖端部， いわゆる真性毛細血管には神経線維の分布が認められなかった。

結論として，これらの神経線維はおそらく，毛細血管の内皮細胞に遠心性の信号を伝達し，下顎煩側歯肉の毛 細血管血流の調整に重要な役を演じるのではないかと思われる。 


\section{Introduction}

Gingival innervation has been investigated using several different techniques. Important contributions have been made by the metal impregnation method, which has demonstrated a rich nervous supply of gingiva in different species ${ }^{1,2)}$. Transmission electron microscopy has revealed the ultrastructure of nerve endings in the propria and epithelium of human ${ }^{3)}$ and $\mathrm{rat}^{4)}$ gingiva. However, those studies mainly described the distribution of nerve fibres on gingival microvasculature itself. The buccal gingiva epithelium directly receives the physical, chemical and thermal stimuli, and shocks of mastication. Microcirculation of gingiva has been reported in rat $^{5-77}, \operatorname{dog}^{8)}$, monkey ${ }^{9}$ and human ${ }^{10)}$. In addition, the capillary network of the gingiva has also been investigated in the golden hamster $^{11}$. The vascular architecture of golden hamster's mandibular gingiva is characterized as blood vessels emanating from the facial artery, running upward along the outer surface of the alveolar bone and dividing into 3 branches. Morphorogical research on the microcirculation system and its nerve distribution enables accurate graphic recostruction of microvasculature through large quantities of paraffin sections or cryo-sections prepared from tissue specimens. However, this is time consuming and cumbersome. The present study was undertaken to investigate the nerve distribution on the capillary network which exists beneath the outer lining epithelium of the gingiva by employing the silver impregnation method on the whole mount gingival specimens testatively.

\section{Materials and Methods}

Ten male golden hamsters (cricetus auratus), aged 3 months and each weighing $100 \sim 150 \mathrm{~g}$, were used in this study. After anesthesia with pentobarbital sodium ( $50 \mathrm{mg} / \mathrm{kg}$ body weight, intraperitoneally), animals were perfused transcardiacally with $4 \%$ formaldehyde saline. To demonstrate the capillary network of the gingiva, India ink ( $10 \%$ gelatin added) was then injected through the same route. The mandible was then quickly removed and stored in the same fixative at

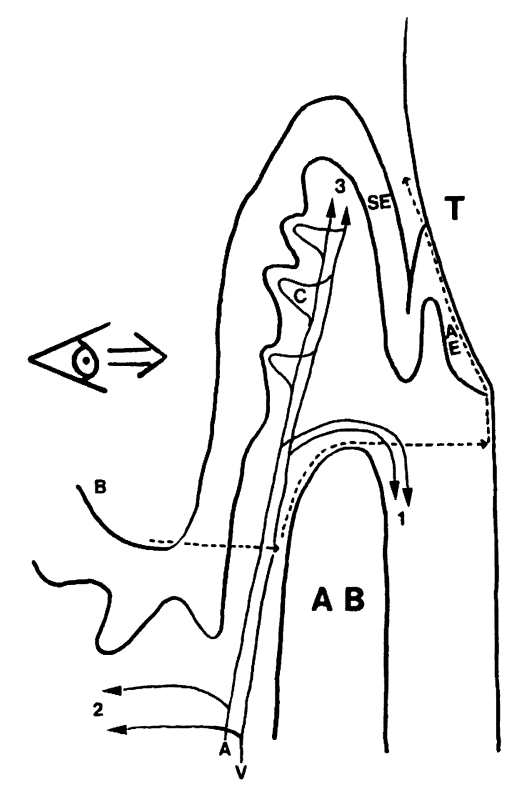

Fig. 1 Enucleation method and microvasculature of the gingiva is illustrated in a scheme. Blant dissection done in the gingiva is indicated in dotted line. A regular network of vessels in the gingiva is composed of 3 ways of vessels indicated by double arrow heads.

$\mathrm{A}:$ arteriole, $\mathrm{V}:$ venule, $\mathrm{T}:$ tooth, $\mathrm{AE}:$ attached epith elium, SE : sulcular epithelium, C: capillary loop, B : buccal side, $\mathrm{AB}$ : alveolar bone.

$4^{\circ} \mathrm{C}$ for $48 \mathrm{hr}$. After fixation, the mandibular buccal gingiva of the molar portion was enucleated carefully for the whole mount specimens. The encleation method and the microvasculature of the gingiva is shown in Fig.1. as a scheme. First, a No.11 scapel was inserted at the transitional portion of the gingivobuccal mucosa perpendicular to the alveolar bone. Blant dissection of the attached gingiva was carried out along the alveolar bone in a direction toward the cervical portion of the molar. Finally, the mandibular buccal molar gingiva was enucleated through dissection of the epithelial attachment at the alveolar crest in a horizontal direction. A regular network of vessels in the gingiva was composed of 3 branches of vessels. The first branch; vessels underlying the crevicular epithelium were continuous with vessels of the periodontal ligment. The second branch; vessels underlying the buccal epithelium were continuous with the vessels of the oral mucosa, and the third branch : 
vessels in the crest gingiva represented the capillary network between the crevicular and buccal networks. In the present study, nerve distribution on the capillary network located beneath the outer lining epithelium of the gingiva as the third branch was investigated by the silver impregnation method. To obtain a much flatter surface of the whole mount gingival specimens, we used 2 pieces of slide glass to clip the specimens. This manipulation was carried out under running tap water and the specimens were rinsed for $2 \mathrm{hr}$. The silver impregnation method, described by Linder, J. $\mathrm{E}^{12}$., was applied on the whole mount gingival specimens directly without preparing paraffin sections. This method was devised to obtain a simple and reliable nerve staining for paraffin sections of soft and mineralized tissue. In brief, specimens were dipped into $0.2 \%(\mathrm{w} / \mathrm{v})$ solution of cellodin in absolute alcohol-ether $(50: 50)$. After careful draining and partial drying, the celloidin film was hardened by immersion in $70 \%$ alcohol. Specimens were then washed, first in running tap water for $30 \mathrm{~min}$, and then in 3 changes of distilled water to remove all traces of fixation. The specimens were then placed in diluted buffer ( $8 \mathrm{mM}$ collidine-nitric acid buffer, $\mathrm{pH}$ 7.2) for $60 \mathrm{~min}$ at $60^{\circ} \mathrm{C}$, then transferred into the silver impregnation solution (2.3 mM silver cynate, $\mathrm{pH} 7.2$ ) for 60 $\min$ at $60^{\circ} \mathrm{C}$. The specimens were washed in serveral changes of distilled water for $30 \mathrm{~min}$ and were then transferred into physical developer (158.6 mM sodium sulfite, $24.9 \mathrm{mM}$ sodium tetraborate anhydrous, $2 \%$ sheet gelatin, $1.12 \mathrm{mM}$ silver nitrate and 9 $\mathrm{mM}$ quinol) at approximately $25^{\circ} \mathrm{C}$. Development of the latent image of the silver impregnated nerve was monitored by first washing in distilled water and then by microscopy. The specimens were then dehydrated with ethanol, cleared in xylene and mounted.

\section{Results}

The full running course of nerve fibres demonstrated by silver impregnation is shown in Fig.2 as a picture (A) and a sketch (B). The sketch was drawn through observations of a selected gingival specimen at different microscopic strengths. The microvasculature of the outer lining epithelium in the gingiva was characterized by many capillaries. The capillaries within the connective tissue papillae orignated from the arterioles of the plexus of the lamina propria which was the base of papillae. Each capillary formed a hairpin-like loop. The overall pattern of the capillary loops replicated that of the papillae that contained them. Regarding the nerve fibres, both myelinated and non-myelinated, were strongly impregnated, well-defined, and clearly differentiated from the vessels which were filled with India ink. Nerve fibres, which were thought to originate from the inferior alveolar nerve, appeared at the periosteum of the alveolar bone and formed bundles. The full running course of these nerve fibres ran longitudinally along the outer surface of the alveolar bone. In addition, nerve fibres accompanied by vessels were found. Nerve fibres running upward and entering into the free gingiva, were random. Nerve fibres branched into many smaller branches and ran toward the connective tissue papillae. Finally, nerve fibres formed mesh-like nerve plexuses immediately beneath the mucosa epithelium of the gingiva. Moreover, single fibres emanating from the nerve plexuses and running upward to the capillary loops were observed at a higher magnification (Fig.3 and Fig.4). In Fig.3, the capillary loop is composed of the arterial portion and the venous portion. The former was named the arterial limb, the latter, the venous limb. Single fibres reached both the base portion of the arterial limb and the venous limb. Furthermore, single fibres ran upward along the venous limb of the capillary loop and enclosed it up to the middle portion. A change in microscopic focus of the same capillary loop, showed other single nerve fibres arising from the plexuses, running upwards and reaching the middle portion of the arterial limb (Fig.4). From these observations, a schematic drawing illustrates the distribution of the nerve fibres on the capillary loop (Fig.5). The capillary loop was simply hairpin shaped, basically consisting of an ascending limb (arterial limb) and a descending limb (venous limb) respectively. Single nerve fibres arising from the nerve plexuses reached not only the middle portion of arterial limb but also the middle portion of venous limb. The nerve fibres formed a dense mesh encompassing the base portion 

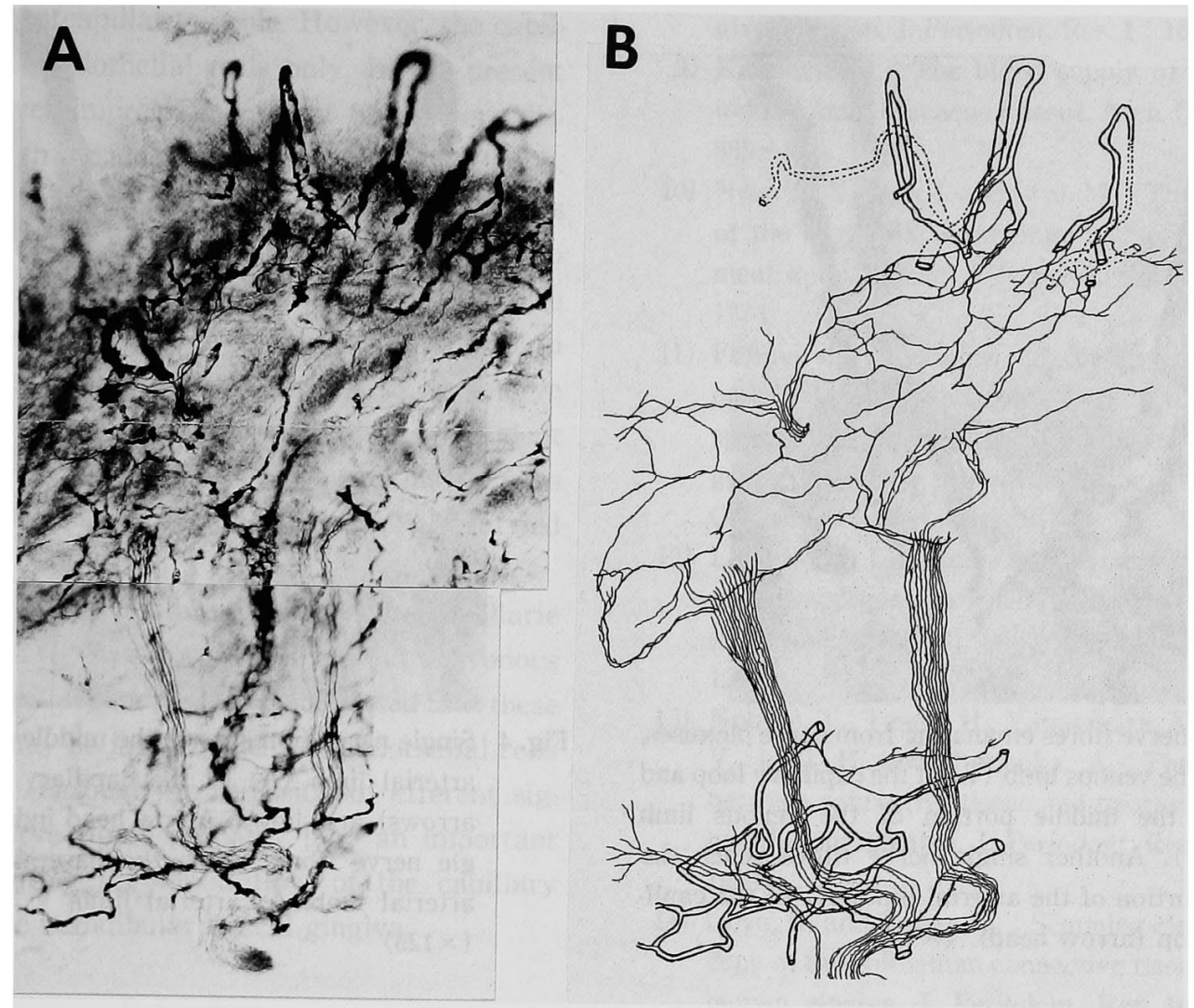

Fig. 2 The full running course of silver impregnated nerve fibres in the whole mount gingival specimens. (A) indicates a combined picture of a selected specimen. $(60 \times)$. (B) indicates a sketch obtained from observing the specimen on the different microscopic focus. The dotted line shown in (B) indicates the posterior row of capillary loops. Nerve fibres appear at the periosteum of alveolar bone, ran longitudinally and upward to reach the capillary loops are shown.

of the arterial limb. The nerve distribution pattern of the arterial limb was different from that of venous limb. Regarding the arterial limb, it was likely that the nerve distribution was more abundent than the venous limb. While the nerve fibres reached a higher position of venous limb than the arterial limb. However, nerve fibres extending to the tip of the capillary loop, the so-called true capillary, were not found.

\section{Discussion}

We attempted to demonstrate the nerve distribution of the capillary network of mandibular buccal molar gingiva in golden hamsters by the silver impregnation method, employing this method on whole mount gingival specimens. Reconstruction of the gingival mi- crovasculature and its nerve innervation from a vast of supply of consective paraffin sections or cryo-sections was not necessary. This method may be a good approach for researching the nerve distribution of capillary networks in the gingiva. Gelatin, added into India ink, was essential and was effective in holding the ink and was retained in the capillary network during the fixative process. The capillary network demostrated clealy and precisely by India ink was sine quo none for this study. The capillaries within the connective tissue papillae, originated from the arterioles of the lamina propria. In addition, capillaries formed loops within the tip of each papilla and then descended and drained into the venules. These capillary loops were simply hairpin shaped, each with an ascending limb (arterial limb) and a descending limb 


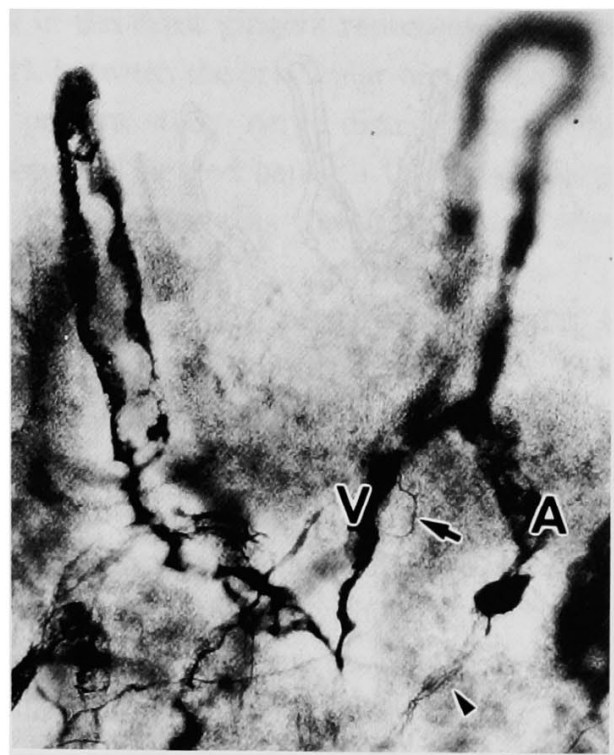

Fig. 3 Single nerve fibres emanating from nerve plexuses, reach the venous limb $(\mathrm{V})$ of the capillary loop and enclos the middle portion of the venous limb (arrow). Another single nerve fibres reach the base portion of the arterial limb (A) of the capillary loop (arrow head). $(\times 125)$

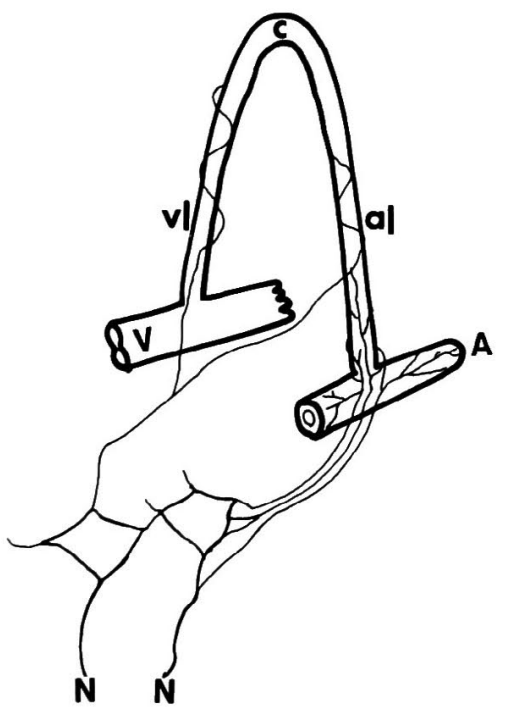

Fig. 5 Nerve distribution of capillary loop is illustrated in a scheme.

Nerve fibres arising from the nerve plexuses, form a dense meshwork enclosing the base portion of arterial limb of the capillary loop. $\mathrm{N}$ : nerve fiber, $\mathrm{A}:$ arteriole, $\mathrm{V}$ : venule, $\mathrm{C}:$ true capillary, al $:$ arterial limb, vl: venous limb.

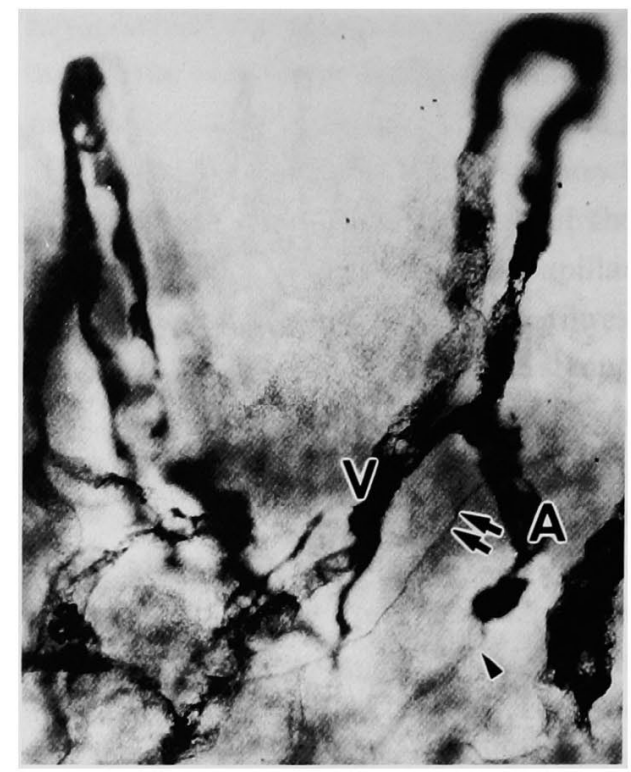

Fig. 4 Single nerve fibres reach the middle portion of the arterial limb (A) of the capillary loop (double arrows) are shown. Arrow head indicates the single nerve fibres reach the base portion of the arterial limb. A : arterial limb, V: venous limb. $(\times 125)$

(venous limb). This finding was in accordance with studies in $\operatorname{dog}^{13)}$ and humans ${ }^{14)}$. As gingival capillaries were derived from arterioles and venules, it was suggested that the entile gingiva vascular bed should be considered as a microcirculation according to the criteria of $\mathrm{Rhodin}^{15,16)}$. Representive repetitive microcirculatory patterns, composed of feeding arterioles, precapillary arterioles, capillaries, postcapillary venules and collecting venules has been described in bat wings by Wiedeman ${ }^{17)}$ and in the mesentery of cats by Frasher and Wayland ${ }^{18)}$. Intaglietta and $Z_{\text {weifach }}{ }^{19}$ demonstrated that the distribution of blood, as well as blood flow volume and rate, are controlled, independently of systemic flow control mechanisms, by the arteriolar and venular vessels of the microvasculature. Regulation of flow by local mechanisms determines the number of capillaries functioning by adjustment of the distribution of blood throughout a microvascular bed. Besides, gingival vessels have been categorised according to the histologic characteristics of the vessel wall by Nuki and $\mathrm{Hock}^{20)}$. Few smooth muscle cells exist on the precapillary arteriole, and pericytes 
exist on the postcapillary venule. However, the capillary itself has endothelial cells only. In the present study, the silver impregnated nerve fibers were distributed on both the arterial limb and the venous limb. In brief, the nerve fibres arising from the plexuses located beneath mucosa epithelium, ran upwards to enclose the base portion of the arterial limb in a dense mesh-like fashion and that of the venous limb in somewhat sparse fashion. It seemed that the nerve distribution on the arterial limb was more abundent than that of the venous limb. However, this remains unclear because quantitative analysis was not carried out.

In conclusion, nerve fibres exist on the capillarie loops, particularly on the arterial limb and the venous limb of the capillary loops. It was suggested that these nerve fibres may be involed with the endothelial cells of capillaries. Through transmission of efferent signals, these nerve fibres probably play an important role in regulating the blood flow of the capillary network in the mandibular buccal gingiva.

\section{References}

1) Dixon, A. D. : Nerve plexuses in the oral mucosa. Arch. Oral. Biol. 8: 435 447, 1963.

2) Tokumitu, Y., Aiba, K., Takahashi, T. and Toyota, $\mathrm{T}:$ On the sensory innervation of gum of dog. Arch. Histol. Jap. $10: 173 \sim 180,1956$.

3) Luzardo-Baptista, M. : Intraepithelial nerve fibers in the human oral mucosa. Oral. Surg. 35 : $372 \sim 376,1973$

4) Martinez, I. R. and Pekarthy, J. M. : Ultrastructure of encapsulated nerve endings in rat gingiva. Amer. J. Anat. 140 : 135 138, 1974.

5) Kindlova, M. and Matena, V. : Blood vessels of rat molar. J. Dent. Res. 41 : 650 660, 1962.

6) Kindlova, M. : The developement of vascular bed of the marginal periodontium. J. Periodont. Res. 5 : 135 140, 1970.

7) Weekes, W. T. and Sims, M. R. : The vasculature of rat molar gingival crevice. J. Periodont. Res. 21 : 177 185, 1986.

8) Egelberg, J.: The blood vessels of the dento-gin- giva junction. J. Periodont. Res. $1: 163 \sim 179,1996$.

9) Kindlova, M. : The blood supply of marginal periodontium in Macacus Rhesus. Arch. Oral. Biol. 10 : 869 874, 1965.

10) Nozaka, Y., Itoh, I. and Iwai, M. : The blood vessels of the crevicular epithelium and epithelial attachment in man. Dent. J. Iwate Med. Univ. 1: $7 \sim 14$, 1976.

11) Fujimura, A.: Studies on the capillary structure underlying the attached epithelium of Golden ham. ster (Cricetus auratus), I. Comparative study of the golden hamster, the rat and the mouse. Shikwa Gakuho 87 : 463 484, 1987.

12) Linder, J. E. : A simple and reliable method for the silver impregnation of nerves in paraffin sections of soft and mineralized tissues. J. Anat. 127 : 543 551, 1987.

13) Nobuto, T., Tanda, H., Yanagihara, K., Nishikawa, Y., Imai, H. and Yamaoka, A. : The relationship between connective tissue and microvascular in the healthy dog gingiva. J. Periodont. Res. $24: 45 \sim 52$, 1989.

14) Ooya, K. and Tooya, Y. : Scanning electron microscopy of the epithelium connective tissue interface in human gingiva. J. Periodont. Res. 16:135 139, 1981.

15) Rhodin, J. : The ultrastructure of mammalian arterioles and precapillary sphincters. J. Ultrastruct. Res. 18:182 223, 1967.

16) Rhodin, J.: The ultrastructure of venous capillaries, venules and collecting veins. J. Ultrastruct. Res. $25:$ 452 500, 1968.

17) Weideman, M. : Dimensions of blood vessels from distributing artery to collecting vein. Circ. Res. 12 : 375 378, 1963.

18) Frasher, W. and Wayland, H. : A repeating modular organisation of microcirculation of cat mesentery. Microvasc. Res. $4: 62 \sim 76,1976$.

19) Intaglietta, M. and Zweifach, B.: Geometrical model of the microvasculature of rabbit omentum from in vivo measurements. Circ. Res. 28: 593 600, 1971.

20) Nuki, K. and Hock, J. : The organisation of the ginginal vasculature. J. Periodont. Res. 9: 305 313, 1974. 